\title{
Organic Agriculture in Least Developed Countries in Relation to the Development of the Organic Farming Sector in Poland The Example of African Countries versus the Organic Sector in Poland
}

\author{
Anna Rydz-Żbikowska \\ Ph.D.,University of Lodz, Faculty of Economics and Sociology \\ Department of Global Economy and European Integration, Lodz, Poland \\ e-mail: anna.rydzzbikowska@uni.lodz.pl
}

\begin{abstract}
Over the past few years, organic farming has seen a dynamic development globally. In 2015, the global market for organic products was $€ 81.6$ billion, rising to more than $€ 90$ billion in 2018 (Światowy rynek produktów ekologicznych osiagnął wartość 90 mld euro 2019). There has also been a significant rise in the production of organic products by the group of Least Developed countries (LDCs) (such as African countries), which are being supported by all the World Trade Organisation negotiations within the Doha Round. The aim of this article is to present different definitions of organic farming according to the most important international organizations. Furthermore, it will examine the status of the organic farming sector in selected examples of Africa's LDCs and investigate the results of Doha's negotiations within the agricultural market (particularly towards LDCs). Finally, it will investigate the status and the latest developments of organic farming in the LDCs compared to Poland. The research methods used in the article include an analysis of available documentary and literary sources on the topics in question, the development of relevant statistical surveys, and the deductive approach to draw conclusions from the development of organic agriculture in LDCs and Poland (as an example of a Central European Country).
\end{abstract}

Keywords: organic agriculture, organic products, sustainable development, least developed countries, World Trade Organisation, Doha Round

JEL: O13, O18, O53, O55, P45, P48, Q01, Q13, Q17, Q18, Q56 


\section{Introduction}

Today, organic farming is seen as one of the best alternatives to conventional agricultural production. This form of cultivation gives huge opportunities for native organic food producers to acquire new sources of income, and it also provides access to new markets. Interest in organic production is growing all over the world. Over the past few years, especially since the mid-1990s, there has been an annual increase of several percent in arable land. It has been reported that the world's area of organic arable land grew by over $530 \%$ between 1999 and 2017, when organic crops accounted for 69.8 million hectares of total organic arable land (FiBL 2019, p. 18). The pace of development of this type of agriculture accelerated at the beginning of the previous decade. However, it should be emphasized that it is diversified in terms of geographical location worldwide and in terms of the area in individual countries (Borowska 2006, pp. 1-2). Undoubtedly, the provisions resulting from negotiations conducted as part of the Doha Round, which have contributed to the lifting of trade barriers in the field of trade in agricultural products and entering the international market, have had a great impact on the development of organic farming, especially in developing and least developed countries (LDCs) (Dugiel 2008, pp. 9-37).

The article's goal is to answer the question of how to understand and define the concept of organic farming. Secondly, it will present how the negotiations within the World Trade Organisation's Doha Round influence the development of the agricultural sector in LDCs and what the key provisions of the actions taken by the organization are. The article also covers organic farming in developing and LDCs, on the example of African countries. Finally, the article explains the current changes (economic, social, institutional, etc.) within the organic agriculture sector of African emerging markets, resulting from the actions taken by the governmental policies. Finally, the article indicates the differences between the development of the organic agriculture sector in LDCs on the example of African countries and the organic sector of Poland (as an example of a Central Eastern European country).

\section{Organic agriculture - defining and understanding the concept}

Organic farming has its roots in traditional agricultural practices, developed over the centuries by small rural communities around the world. Farmers have passed on their knowledge of effective practices from generation to generation. Organic farming became more widely recognized in the 1940s, when both farmers and consumers began to recognize the problem of excessive use of chemicals for plant production and animal husbandry. They also realized that this could have negative consequences for human health and the environment (European Commission 2012, pp. 1-2). Organic farming has since grown into a more coherent and organized movement, and it is now one of the 
fastest-growing food sectors in the world (FAO 2012, pp. 5-6). It is worth underlining that the first organic agriculture organizations and farmers' associations date back to the 1940s, including the first organic labels, Bioland and Bio Suisse in Switzerland, and Demeter in Germany. One of the milestones for the development of organic agriculture was the establishment of the Federation of Organic Agriculture Movements (IFOAM) in 1972, as a forum for different parties engaged in this sector (European Commission 2012, pp. 1-2).

Referring to the definition of the Food and Agriculture Organization of the United Nations (FAO), organic farming involves cultivation techniques that do not use artificial fertilizers and pesticides. However, it should be emphasized that this statement does not set the basic framework for such agriculture; it only identifies agriculture with a method of land management in which the major concern is to prevent all problems related to soil fertility, its erosion, and harmful pests. The FAO identifies organic farming as a system of plant cultivation, animal husbandry, and fisheries that emphasizes the importance of environmental protection and the use of natural agricultural techniques (FAO 1999). This system focuses not only on the control of the final product but also on the entire process of producing and delivering the organic product to the final consumer. The entire production, processing, handling, and transport cycle of organic farming excludes the use of artificial products, such as genetically modified organisms (GMOs) and specific external agricultural agents (pesticides, veterinary agents, medicines, artificial additives, and fertilizers) (European Network for Rural Development 2014, pp. 1-2). Organic farmers rely on natural farming methods, and they also benefit from modern knowledge of ecology to maximize the productivity of ecosystems, improve the quality of organic products, and protect the environment (Kristensen, Reganold and Taji 2006, pp. 3-5).

The definition of the International Federation of Organic Agriculture Movements (IFOAM) for organic agriculture is based on four main principles: health, ecology, fairness, and care (Luttikholt 2007, pp. 347-360). In 1996, IFOAM defined the term "organic" as an expression that refers to a specific plant-growing system set out by basic standards. The main goals of organic agriculture and processing (Principle Aims of Organic Agriculture and Processing) are based on the following equally important objectives and ideas (FAO 1998, p. 4):

- to produce food of high nutritional quality in sufficient quantity;

- to interact in a constructive and life enhancing way with all natural systems and cycles;

- to encourage and enhance biological cycles within the farming system, involving micro organisms, soil flora, and fauna, plants, and animals;

- to maintain and increase long-term fertility of soils;

- to promote the healthy use and proper care of water, water resources, and all life therein;

- to help in the conservation of soil and water; 
- to use, as far as is possible, renewable resources in locally organized agricultural systems;

- to work, as far as possible, within a closed system with regard to organic matter and nutrient elements;

- to work, as far as possible, with materials and substances which can be reused or recycled, either on the farm or elsewhere;

- to give all livestock conditions of life which allow them to perform the basic aspects of their innate behavior;

- to minimize all forms of pollution that may result from agricultural practices;

- to maintain the genetic diversity of the agricultural system and its surroundings, including the protection of plant and wildlife habitats;

- to allow everyone involved in organic production and processing a quality of life conforming to the UN Human Rights Charter, to cover their basic needs and obtain an adequate return and satisfaction from their work, including a safe working environment;

- to consider the wider social and ecological impact of the farming system;

- to produce non-food products from renewable resources, which are fully biodegradable;

- to encourage organic agriculture associations to function along democratic lines and the principle of division of powers;

- to progress towards an entire organic production chain, which is both socially just and ecologically responsible.

The Organization for Economic Cooperation and Development (OECD), in turn, defines organic farming as "a cultivation system that avoids the use of artificial fertilizers and pesticides or herbicides by using organic fertilizers and various methods of crop rotation" (FAO 2012).

Summarizing all the above definitions of organic agriculture, it can be concluded that the cultivation of organic products is based on the principle of reducing the number of fertilizers, taking care of the environmental protection, using renewable sources of energy, implementing sustainable methods of production, and improving the development of rural areas.

\section{The provisions of the Doha Round and the Issue of Developing and Least Developed Countries}

The Doha Round is the latest round of negotiations on world trade among WTO members, with negotiations in its forum still underway. Its main task is to carry out many reforms in the global trade system by providing smaller trade barriers and correcting global trade rules. Negotiations under the Doha Round cover twenty-one trade areas. This round is also unofficially called the Doha Development Agenda because its fundamental goal is to improve the trade prospects of developing countries. 
The round officially began its negotiations at the Fourth Ministerial Conference in Doha, Qatar, in November 2001 (Zajączkowski 2018, pp. 205-28). The Doha Ministerial Conference commissioned negotiations, including negotiations on agriculture, services, and intellectual property, which had already begun during the WTO's Uruguay Round (Martin and Mattoo 2011, pp. 1-55). During the Doha Round, ministers also approved the decision to include provisions related to solving problems faced by developing countries in the current WTO agreements (Wojtas 2008, pp. 219-222). The WTO's task is to facilitate trade flows, making them more fluid and predictable. Negotiation works are carried out in two ways: firstly, by abolishing and reducing trade barriers (where possible), and secondly, creating rules to maintain trade barriers and trade policies. All these activities are the result of negotiation rounds that have been conducted between the governments of individual countries since 1940 (Buckley 2003). The Doha Round continues this tradition and is the ninth round since the end of the Second World War and the first since the adoption of the multilateral trading system in 1995. Its mission is to make the first and most revolutionary change in the world trading system in the $21^{\text {st }}$ century (Ancharaz 2012, pp. 102-110).

The problem of developing countries entering the global market and conducting free trade policy was reflected in the provisions and a series of procedures that are the result of negotiations within the Doha Round. As mentioned before, one of the priority goals of the Doha Development Agenda is to increase development prospects in trade for developing countries. Currently, a large number of developed countries have significantly reduced or even abolished customs duties on imports from LDCs. In the Doha Round Declaration, WTO member countries aim to remove tariffs, quantitative restrictions, and any barriers to access the international market for products from LDCs. Additionally, WTO member governments are considering the possibility of introducing additional measures to improve market access for such export products. WTO members also agree that it is essential to ensure that LDCs negotiate with WTO members in a simplified and faster manner. The WTO has also introduced special technical support, which is targeted especially at LDCs. The Doha Declaration also recommends WTO donor members significantly increase their financial contributions. In this regard, the Sub-Committee for LDC's, which is an auxiliary unit for the WTO Trade and Development Committee, developed a special work program in February 2002, consistent with the requirements of the Doha Declaration and provisions regarding trade approved at the United Nations Conference on Least Developed Countries (UN LDC Conference) (WTO 2019). The task of the Sub-Committee for the benefit of the Least-Developed Countries is foremost to consider such matters and solve problems, which from the view of these countries, are of the greatest importance. It is worth noting that, as in the Trade and Development Committee, all WTO members are also members of the Sub-Committee for Least Developed Countries.

Since the Doha Ministerial Conference in 2001, the LDCs Sub-Committee has focused on implementing the work program for the Least Developed Countries. The work program is focused on the following topics (WTO 2019): 
- market access for LDCs;

- technical assistance in commercial matters and initiatives for capacity building in LDCs;

- assistance to agencies that support production and develop the export base in LDCs;

- creating mainstream activities (where needed) in the work of the WTO concerning trade-related elements under the implementation of the $3^{\text {rd }}$ LDC program of activities;

- the participation of LDCs in the multilateral trading system;

- the accession of LDCs to the WTO;

- the compatibility of LDCs to ministerial decisions/declarations established by the World Trade Organization.

The Sub-Committee for the Least Developed Countries also monitors the work carried out under the integrated technical assistance framework related to trade for the LDCs. The WTO recognizes LDCs as those countries that are described as such by the United Nations. ${ }^{1}$ Presently there are 47 LDCs on the UN list, 36 of which are members of the WTO. Eight LDCs are in the process of joining the WTO: Bhutan, Comoros, Ethiopia, Sao Tome and Principe, Somalia, South Sudan, Sudan, and Timor-Leste (WTO 2019).

One of the major spheres of negotiations within the Doha Round for the LCDs is the agricultural sector. Negotiations on agricultural trade began in early 2000 and became a part of the Doha Round at the 2001 Doha Ministerial Conference under the original mandate of the Agriculture Agreement. In 2013, during the Bali Ministerial Conference, vital agricultural decisions were adopted by the ministers. The outcomes of the Bali Conference included (WTO 2020a):

- "an agreement to negotiate a permanent solution to public stockholding for food security purposes, and to refrain from challenging breaches of domestic support commitments resulting from developing countries' public stockholding programmes for food security provided certain conditions are met;

- a call for more transparency in tariff (or tariff-rate) quota administration - whereby quantities inside a quota are charged lower import duty rates - and for governments not to create trade barriers by how they distribute quotas among importers;

- an expansion of the list of "General Services" - to include spending on land use, land reform, water management, and other poverty-reduction programmes -that qualify for Green Box support (i.e., domestic support that is allowed without limits because it does not distort trade, or at most causes minimal distortion);

- a declaration to reduce all forms of export subsidies and to enhance transparency and monitoring".

1 The Least Developed Countries (LDCs) is a list of developing countries that, according to the United Nations, are described by the lowest indicators of socioeconomic development and with the Lowest Human Index ratings of all countries in the world. The concept of LDC's originated in the late 1960s and the first group of LDCs was lited by the UN in November 1971. 
The historic decision to eliminate agricultural export subsidies should be considered the greatest milestone for the WTO Nairobi Ministerial Conference in 2015 towards the negotiations on agricultural trade. The idea was to establish new mechanisms for export measures that would have an equivalent effect. As a result of the decision, developed countries will immediately eliminate export subsidies, with the exception of a few agricultural products, while developing countries would have an extended time to put all the changes into force (WTO 2020b). The elimination of export subsidies has led to the key objective of Sustainable Development Goals, which is Zero Hunger. WTO members also agreed to participate in finding a sustainable solution for developing countries to take advantage of public stockpiling programs for food security purposes.

Ministers also decided to continue negotiations on a special safeguard mechanism that would allow developing countries to temporarily raise customs duties on agricultural products in the event of a sharp increase in imports or falling prices (WTO 2020b). Understanding the importance of the level of commodity dependence of developing countries is crucial in that case. According to the latest statistics of an UNCTAD survey on the state of commodity dependence in 2019, commodity dependence is mostly concentrated in the least developed and most vulnerable country groups: $85 \%$ of LDC's, $81 \%$ of landlocked developing countries, and $57 \%$ of small island states. Only $13 \%$ of developed countries can be described as commodity-dependent, in comparison to $64 \%$ of developing and $66 \%$ of transition economies, makes a huge difference (OECD 2019, pp. 4-5). More importantly, 20\% of commodity-dependent countries are dependent on agriculture, $17 \%$ on minerals, and the same amount on energy (32 countries) (OECD 2019, p. 4). The vast majority of commodity-dependent (agriculture-dependent) least developed and developing countries are African and South American countries. Furthermore, according to the World Bank country classification by income group, $91 \%$ of low-income countries are reliant on the export of goods, compared with less than one-third of high-income countries (OECD 2019, p. 5). Thus, it is necessary to support the least developed and developing countries in their struggle to expand their agriculture markets.

\section{The latest changes in organic agriculture of Least Developed Countries on the example of Africa - statistics and developments}

Most developing and least developed countries take advantage of the agriculture sector to boost their economies. According to a Working Paper of the UN Economic and Social Commission for Asia and the Pacific (ESCAP 2014, p. 5), the development of that sector should be seen as a crucial priority for the inclusive and sustainable development of LDCs. While in developed countries, organic agriculture is an ecologically, 
economically, and socially justified solution to reduce the amount of surpluses and to gain crops from unused land, in least developed and developing countries, organic agriculture is grounded in generating profits from agriculture by promoting organic foodstuffs (Scialabba and Hattam 2002, p. 1). More importantly, the non-profit objectives of organic production are not supported by the governments of the majority of developing countries, though there are some exceptions, like India, Uganda, or Zambia. For most developing countries, well-managed organic production systems may increase the productivity of agriculture and have a positive effect on restoring natural resources (Schoonbeek et al. 2013, pp. 917-928). Another issue is the need to restructure agricultural policies in developing countries and to reorientate them into more food security objectives (Scialabba and Hattam 2000, pp. 1-10).

Slightly more than $70 \%$ of countries listed as LDCs by the United Nations Conference on Trade and Development are African. This would be the main reason to base further considerations on organic agriculture and its development on that continent. Another reason would be because African countries base their economies on exports of agricultural products (almost 19\% of food and agriculture primary commodities exports in 2015-2017 by African LDCs and Haiti) (UNCTAD 2018, p. 16).

\section{Main statistics on organic agriculture in Africa}

According to the latest report on organic agriculture worldwide (IFOAM 2019), there were nearly 2.1 million hectares of agricultural land in 2017 in Africa, which represents $0.2 \%$ of the continent's agricultural area, and around $3 \%$ of the total organic agricultural area worldwide.

Organic agricultural land in Africa is constantly growing (an increase of 14\% in 2017 compared to 2016), which can be observed by an increase of more than 2 million hectares compared with 52,000 hectares in 2000. There were 44 countries in Africa that published reports on organic activities in 2017. The leading countries were Tunisia (the largest organic area, with almost 306,500 hectares), Uganda (with the highest number of organic producers, with over 210,000), and Sao Tome and Principe (with the highest organic share of the total agricultural land, with $18 \%$ of its agricultural area being organic, followed by Tunisia with 3\% and Egypt with 2.8\%). 
Organic Agriculture in Least Developed Countries in Relation to the Development...

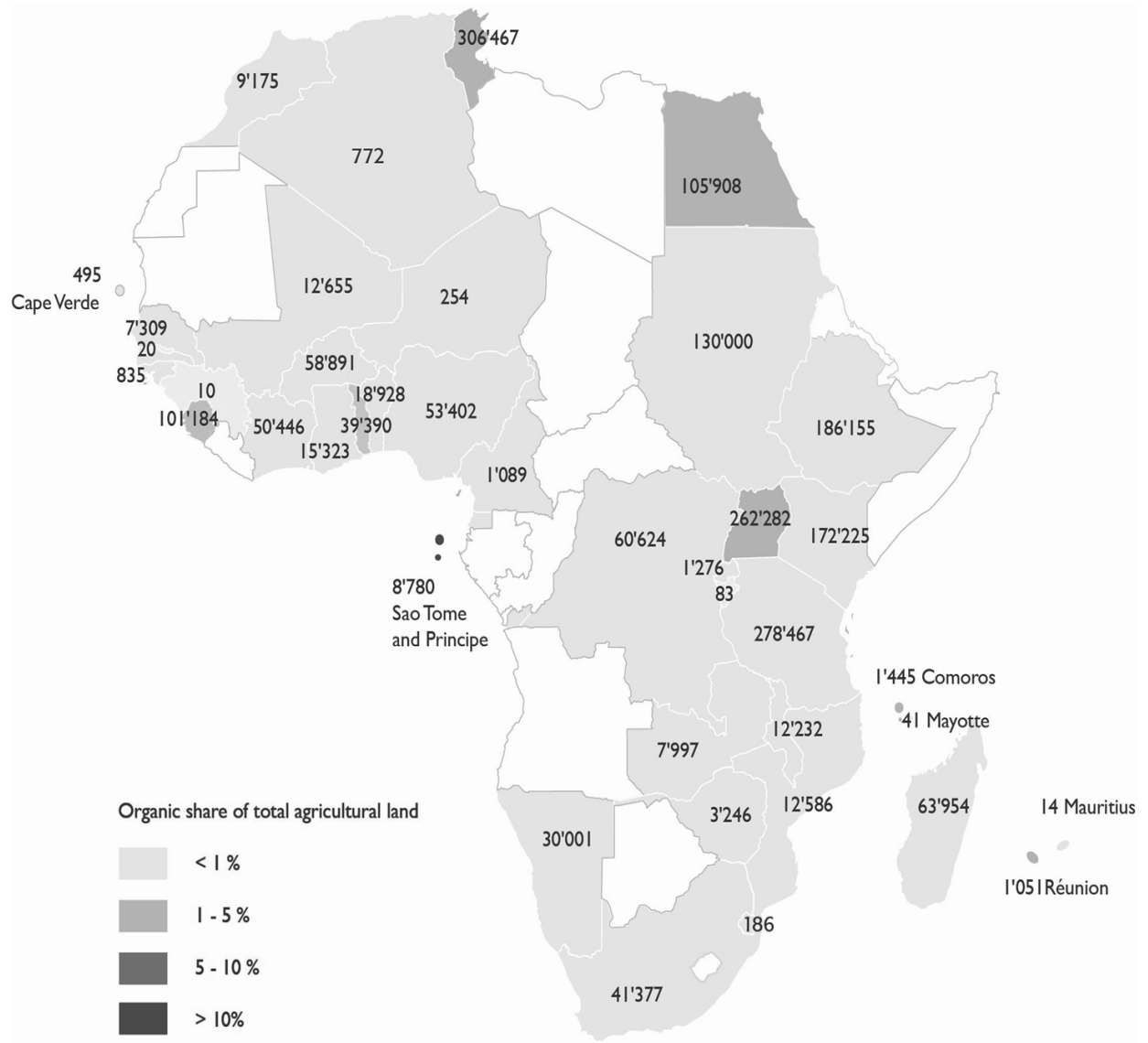

Figure 1. Organic agricultural land in countries of Africa 2017 (in hectares)

Source: FiBL survey 2019, based on information from the private sector, certifiers, goverments and for North Arica, the Mediterranean Organic Agricultural Network (MOAN), Julia Lernoud, Helga Willer and Bernhard Schlatter, Africa: Current Statistics in Willer and Lernoud 2019, p. 173. 


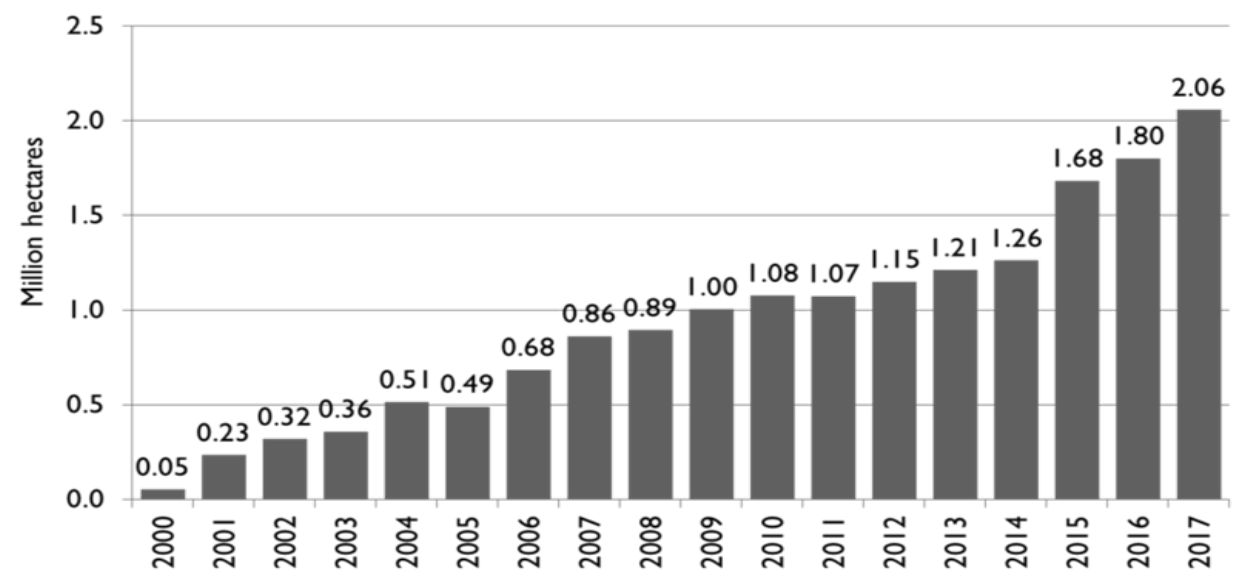

Figure 2. Development of organic agricultural land in Africa (2000-2017)

Source: FiBL-IFOAM-SOEL-surveys 2000-2019, Julia Lernoud, Helga Willer and Bernhard Schlatter, Africa: Current Statistics in Willer and Lernoud 2019, p. 182.

\section{Land use}

In 2017, over half of the organic agricultural land was used for permanent crops (around 1.3 million hectares), almost 30\% was dedicated to arable crops (over 599,000 hectares), and nearly $2 \%$ (82 700 hectares) was grassland and grazing area (there was no data for $8 \%$ of organic agricultural land in Africa).

The largest permanent crop areas were reported in the following countries:

- Tunisia (274,000 hectares, mainly olives),

- Uganda (almost 170,700 hectares, mainly cocoa),

- Ethiopia (161,000 hectares, mainly coffee),

- Kenya (over 127,000 hectares, mainly nuts, and coconuts),

- Tanzania (almost 107,000 hectares, mainly coffee.

One of the major permanent crops is coffee, covering more than 373,000 hectares. It also constitutes $12.4 \%$ of the total coffee area of the region. Tanzania (almost 82,000 hectares) and Ethiopia (over 160,000 hectares) are the leaders in organic coffee areas. According to the FIBL statistics, the organic coffee area has increased 20 -fold since 2004 , but it should be noted that some of the increase might be the result of data availability. But what is even more interesting is the increase in cocoa yields, which has grown 64-fold since 2004. Cocoa was grown on almost 111,000 hectares, and the largest areas of organic cocoa were found in the following countries:

- Democratic Republic of Congo (51,900 hectares),

- Sierra Leone (43,300 hectares),

- Uganda (over 19,000 hectares). 
Organic Agriculture in Least Developed Countries in Relation to the Development...

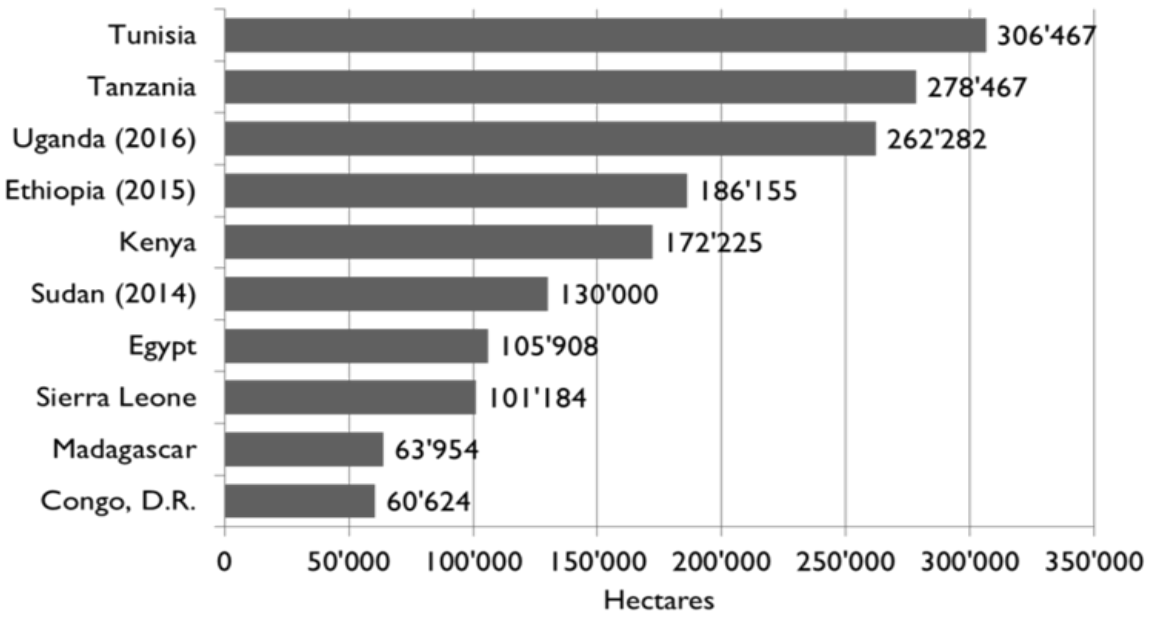

Figure 3. Leading African countries with the largest organic area in 2017 (in hectares) Source: FiBL survey 2019, based on information from the private sector, certifiers and goverments, Julia Lernoud, Helga Willer and Bernhard Schlatter, Africa: Current Statistics in Willer and Lernoud 2019, p. 183.

Arable crops represented almost $30 \%$ of the total organic farmland in Africa (FIBL 2019). The most commonly grown plants were:

- oilseeds (almost 236,500 hectares, $0.9 \%$ of the total oilseed area; mainly sesame),

- textile crops (119,000 hectares, $2.3 \%$ of the region's total cotton area),

- cereals.

Cotton plays a significant role in the organic production of Africa. Almost $60 \%$ of the region's cotton originates from Tanzania (almost 68,500 hectares), followed by Sudan (15,000 hectares). The total organic cotton area has grown 12 -fold since 2004.

Cereals, as the third type of most commonly grown plants within organic agriculture in Africa, were grown on over 66,000 hectares in 2017. The leading countries in that type of production were:

- Tanzania (almost 51,000 hectares),

- Egypt (over 8000 hectares),

- Senegal (almost 3700 hectares).

\section{Organic producers}

Organic producers in Africa play a significant role in shaping the whole system of organic production and implementing new standards of agricultural practices. The number of organic producers in Africa has steadily grown since 2010, when there were 540,000 organic producers. By 2017, the number had reached 815,000 . 
Among countries with the most organic producers might be listed:

- Uganda (over 210,000),

- Ethiopia (over 203,000),

- United Republic of Tanzania (148,000).

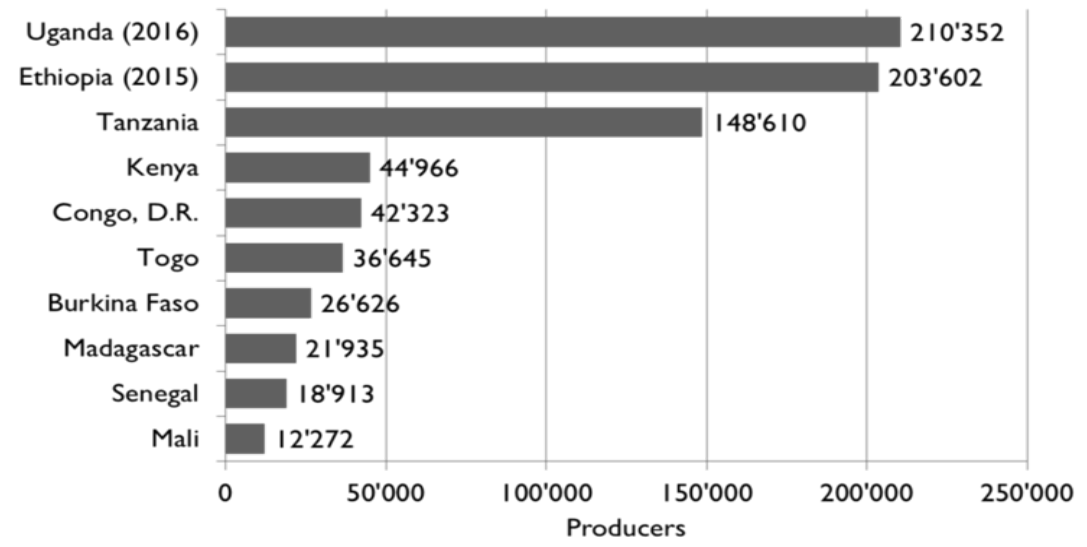

Figure 4. The ten African countries with the largest number of organic producers in 2017 Source: FiBL survey 2019, based on information from the private sector, certifiers and goverments, Julia Lernoud, Helga Willer and Bernhard Schlatter, Africa: Current Statistics in Willer and Lernoud 2019, p. 183.

\section{Wild collection}

Within organic agricultural production in Africa, wild collection plays a significant role and should be seen as a crucial part of that system. There were over 14.3 million hectares of wild collection that were certified as organic in 2017. Plants widely used in medicine, such as devil's claw, are the type of crops that represent the largest area (over 2.5 million hectares), followed by oil plants (almost 737,000 hectares), such as argan. Leaders of organic wild collection include African LDCs such as Zambia (the largest area - more than 5.9 million hectares, beekeeping in particular), followed by Tanzania (2.4 million hectares, mainly beekeeping), Mozambique (over 844,000 hectares, coconuts as a major crop), and Somalia (more than 807,000 hectares, mainly natural gums). Namibia (1.3 million hectares) and South Africa (1.3 million hectares) are the countries with the highest share of devil's claw crops.

The most important activity in organic wild collection in Africa is beekeeping, with almost 7.8 million hectares. The unquestionable leader in that activity is Zambia, with the largest wild collection area used for organic beekeeping (5.9 million hectares, representing $67 \%$ of the total beekeeping area). 


\section{Ecological organic agriculture in Africa - perspectives and challenges}

Nowadays, organic agriculture and production in Africa are seen as outstanding successes by organic producers (farmers, processors), policymakers, stakeholders, and practitioners. They also play a vital role in reducing the problems of soil degradation and climate change, overcoming food insecurity, and inhibiting poverty. There are different initiatives to support the organic agriculture system in Africa and to foster sectoral policies into more organic-oriented ones. Another issue is the efforts to develop marketing and to enhance the value chain of organic production, or to implement different kinds of curricula in some academic institutions (Gama 2018).

The development of organic farming in Africa is entering a new phase. The awareness that this kind of production is the most suitable path to the development of African countries contributes to changes in sectoral policies. The most important breakthrough in African agriculture was undoubtedly the African Union's decision to support organic farming, as well as its ongoing leadership in promoting future strategies and framework conditions for organic farming policies, such as the African Ecological Organic Agriculture Initiative (EOA-I) or the IFOAM-Africa Union Conference. Undoubtedly, the Ecological Organic Agriculture Initiative had many positive effects, such as establishing a database on research findings and knowledge on ecological organic agriculture, available and accessible for various users (Ecological Organic Agriculture Initiative 2015). Summing up, two-third of recipients reached by the EOA Initiative in participating countries (Kenya, Tanzania, Uganda, Ethiopia in East Africa, Nigeria in West Africa, and Zambia in Southern Africa) are already aware of EOA practices and technologies (FiBL \& IFOAM 2020, p. 186). It is also reported that $58 \%$ of organic producers have noted more than a $10 \%$ increase in their incomes, while $73 \%$ observed an increase in their life status. Still, there is much to be done, as many obstacles in the transition to being organic have been declared by the farmers. Another concern is farmers' fears about social exclusion, the scarcity of well-organized value chains, low economies of scale, and a clearly visible lack of knowledge at all levels.

There are more initiatives that support the development of organic agriculture in Africa, such as:

- the African Organic Network "AfroNet" (umbrella body to unite and to motivate non-state African ecological/organic stakeholders);

- the Network of Organic Agriculture Researchers in Africa "NOARA" (network established by African organic agriculture researchers).

The roles of NOARA include supporting capacity building for key players in organic and ecological agriculture across the continent, developing organic agriculture research, additional training, value chains and market development, mobilizing resources for promoting organic agriculture, and providing management and administrative consultancy to partners on mind-based programs (FiBL \& IFOAM 2020, pp. 188-191). 


\section{The sector of organic agriculture in Poland - latest statistics and trends}

The roots of organic farming in Poland can be traced back to 1924, when Stanislaw Steiner organized a course aimed at disseminating the principles and scope of organic agriculture, called biodynamic agriculture at the time (Runowski 2003, pp. 245-262). However, the process and methods of that kind of agriculture have changed a lot since then, and today, the organic agriculture system in Poland is based on European standards, and it is in line with all the regulations defined by the Common Agriculture Policy of European Union. After the accession to the European Union, the number of organic farms and the area of farmland managed organically increased significantly in Poland, as it had done before in other Member States (Kowalska 2015, pp. 467-476).

Between 1999 and 2013, the number of organic agricultural producers increased from 27 to 27,093, i.e., over 1003 times, while the cultivated area increased from 300,000 to 669,969 ha, i.e., as much as 2.2 times. The largest increase in the number of producers and the cultivation area took place in 2010, when the number of producers increased by 3533 compared to the previous year, while the area increased by 1.02 million hectares. Between 2004 and 2013, the area of ecological agricultural land in Poland increased 8-fold (from 82,730 ha in 2004 to 669,969 ha in 2013) (Makowska, Gotkiewicz and Pawlewicz 2015, pp. 161-163).

Organic agriculture plays a significant role in the development of rural areas and the improvement of standards of living for farmers in Poland. There has been huge interest and additional efforts to support organic production in Poland since 2001, when legal regulations regarding the production of organic food were introduced, as well as subsidies from the state (Kuś and Jończyk 2009, pp. 178-182).

Nowadays, the control system of organic production in Poland, as in most EU countries, is delegated to certification bodies that are authorized and supervised by a designated authority. The Minister of Agriculture and Rural Development, as a major authority, is responsible for authorizing certification bodies to conduct inspections as well as issuing and withdrawing certificates in organic farming. The second authority is the Agricultural and Food Quality Inspection (2019), which is responsible for supervising certification bodies and organic production (IJHARS 2019, pp. 10-12).

\section{Current statistics on the organic agriculture sector in Poland}

In 2019, there were 20,146 entities active in organic farming, including 18,656 organic farmers managing an area of 5.05 million hectares. The largest area of ecological agricultural land was occupied by cereal crops, followed by permanent grasslands.

According to the latest report on organic agriculture in Poland prepared by the Agricultural and Food Quality Inspection, the number of organic producers decreased 
by $8.4 \%$ in 2017 compared to 2016, and it fell again in 2018 by 4\%, from 21,400 in 2017 to 20,549 . By analyzing the data on the number of organic producers, the period between 2017 and 2018 was the second time since 2014-2015, when a decrease was recorded. In 2018, compared to 2016 and 2017, the number of organic agricultural producers decreased (by $14.4 \%$ and 5.2\%, respectively). However, in 2017-2018, a significant increase in the number of ecological entities dealing with the preparation of organic farming products was noted (by $12.8 \%$ in 2017 , and by $14.5 \%$ in 2018 ).

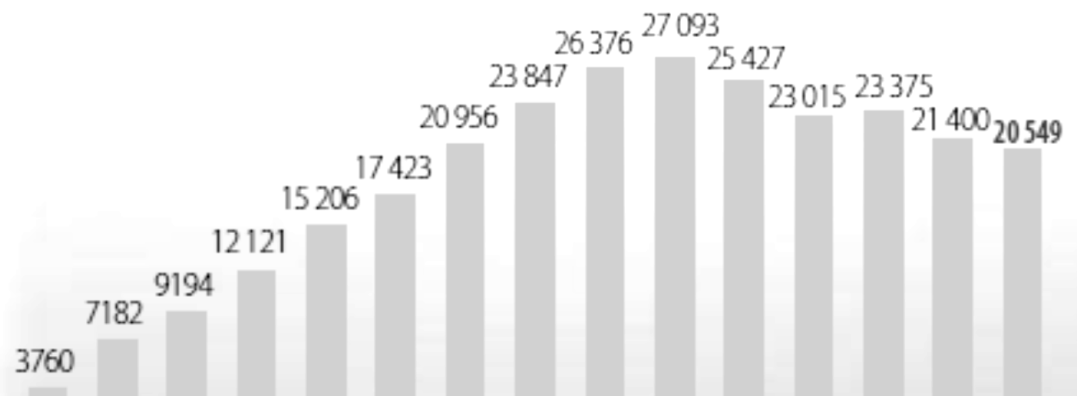

200420052006200720082009201020112012201320142015201620172018

Figure 5. Number of organic producers in Poland in 2004-2018

Source: Agricultural and Food Quality Inspection 2019, p. 22.

In 2018, most of the organic producers (out of the total number of 20,549) operated in the following voivodeships: Warmińsko-Mazurskie (3420 producers, who accounted for $16.6 \%$ of the total number of organic producers in Poland), Podlaskie (3022 producers; $14.7 \%$ ) and Mazowieckie (2648 producers; 12.9\%). These voivodeships were also the leaders in terms of the number of farms: Warmińsko-Mazurskie (3393), Podlaskie (2989), and Mazowieckie (2284). The number of organic farms in these three voivodships (8666) accounted for almost half (45.1\%) of all organic farms in Poland in 2018.

The total area of ecological agricultural land in 2018 reached 484,676.2 ha, of which $75.0 \%$ was agricultural land where the conversion had been completed, and $25.0 \%$ was during the conversion period. The largest area of ecological agricultural land was found in the following voivodeships: Warmińsko-Mazurskie (104,573.3 ha) and Zachodniopomorskie $(92,891.8$ ha), accounting for $40.7 \%$ of the ecological land in Poland. The voivodships with the smallest area of ecological agricultural land were Śląskie (2951.3 ha) and Opolskie (3553.9 ha). If we look at the statistics and data on the ecological area in Poland, the total area of organic agricultural land in Poland has steadily decreased since 2013, which shows a negative trend in that sphere.

It is important to compare Poland's statistics on organic land with those of the European Union and draw conclusions. In 2017, the total area of ecological agricultural 
land in the European Union was over 12.5 million hectares, which accounted for 7\% of the agricultural area in the community; in Poland, it was only $3.4 \%$. Since 2012, the area of ecological land in the EU has increased by $25 \%$, while at the same time in Poland, it has decreased by almost 25\%. Nevertheless, since 2014, organic plant production in Poland has increased, and this has been done in almost all groups of crops except for fodder plants. Between 2014 and 2018, the number of animals (except broilers) kept on organic farms decreased, and there was also a decrease in certified animal production, e.g., meat and milk.

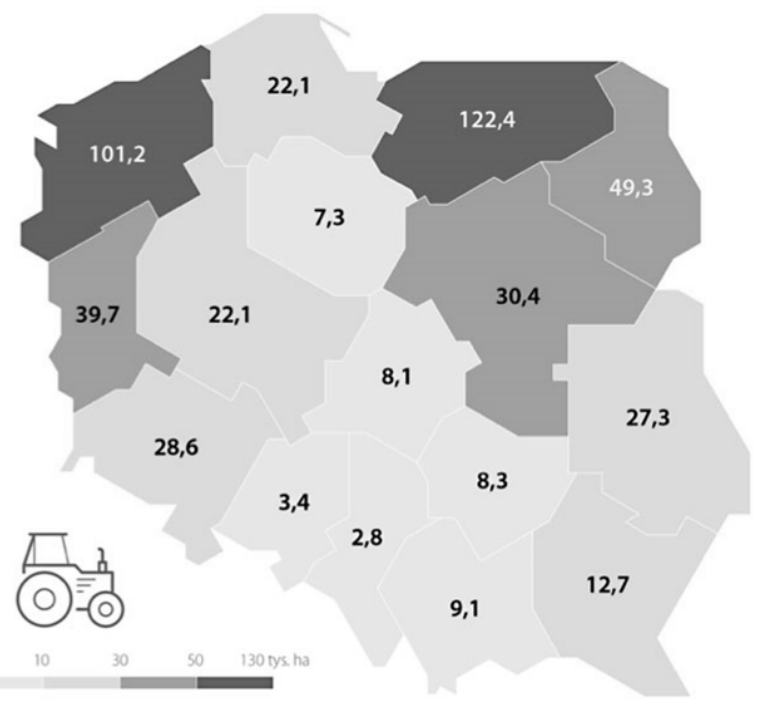

Figure 6. The area of ecological agricultural land in Poland in 2018 according to voivodships (in thousand hectares)

Source: own study of the Supreme Audit Office based on statistical data prepared by Agricultural and Food Quality Inspection - Jak państwo wspiera ekorolników 2019.

Since 2014, the number of processing plants has almost doubled, and in 2018 there were already 910, with the largest number in the Mazowieckie, Wielkopolskie, and Lubelskie voivodships. However, this is still not much compared to the countries of Western Europe. According to Eurostat, in 2017, there were 18,500 people in Italy dealing with processing plants, and approx. 15,000 in Germany and France. Spain was fourth in this ranking, with over 4000 organic processors (Eurostat 2019 - Agricultural production - crops 2019).

In August 2018, the Ministry of Agriculture and Rural Development estimated the value of the Polish organic food market at approximately PLN 1 billion. However, its share in the food market is only $0.3 \%$, while in 2017, the average in the European Union was 4\%; in record-breaking Denmark, it was almost 8.5\%, in Switzerland almost 8\%, and in Austria 6.5\% (Supreme Audit Office 2019 - Ministry of Agriculture and Rural Development 2020). 
In 2019, there were 20,146 entities active in organic farming, including 18,656 organic farmers managing an area of 505,700 hectares. The largest area of ecological agricultural land was devoted to cereal crops, with permanent grasslands in second place. In 2019, the production of eggs and fish significantly increased in livestock production, and the number of animals, especially poultry, increased. The number of entities preparing organic products has increased significantly, numbering 967 in 2019. Each organic certification body makes information available on the Internet about the organic producers it controls. Currently, the control of organic producers is carried out by 13 authorized certification bodies (Ministry of Agriculture and Rural Development 2020).

According to the data cited by the Warsaw University of Life Sciences, currently, about $50-60 \%$ of organic products that are transferred to retail sale in Poland come from import, in particular, exotic fruit and their preserves, coffee and tea, highly processed products, and spices. Our producers mainly export fresh and frozen fruit and vegetables, apple juice concentrate, as well as grains and grain products (Supreme Audit Office 2019 - Jak państwo wspiera ekorolników 2019).

The Supreme Audit Office in Poland believes that organic farming has a chance to become a significant element in the development of the entire Polish agriculture sector, provided that the strengths of this type of production are used. The greatest strengths of Polish organic production include low environmental pollution, the predominance of small and medium-sized family farms, large natural resources, as well as relatively low labor costs, relatively low consumption of chemicals, the price competitiveness of Polish ecological products on the EU market, and introduction of European subsidies for organic production and from the national budget (Supreme Audit Office 2019 - Jak państwo wspiera ekorolników 2019).

Nevertheless, it should be noted that the profitability of production and the profits that can be achieved by ecological entities are the most important issues for the development of the organic agriculture sector in Poland. The desire to increase the supply or the range of organic products on the market is of secondary importance (Kowalska 2015 , pp. 467-476). The same conclusion was drawn on the organic sector in LDCs in African countries.

\section{Conclusion}

Organic agriculture can be seen as one of the methods of sustainable farming. This method aims to obtain optimal, high-quality crops without the use of synthetic fertilizers or chemical pesticides. The principles of organic farming are based on the holistic treatment of basic biological processes. It draws attention to the fact that the optimal course of life processes is achieved only in the closed circulation of biological substances (soil - plant - animal - human). Organic agriculture plays a significant role in the development of rural areas and improving farmers' quality of life. It has a positive effect 
not only environmentally but also economically and socially. Agriculture, as a sector, is undoubtedly one of the most important spheres in the economic sense for LDCs. The WTO's Doha Round aims to improve global trade rules and provide smaller trade barriers, in particular, for LDCs. It is also one of the most important negotiation rounds to remove all the export subsidies for agricultural products, which favors developing economies. Furthermore, the elimination of export subsidies is a step towards fulfilling the key objective of the Sustainable Development Goal, which is Zero Hunger.

Africa represents over $70 \%$ of the world's least developed countries. Most of them take advantage of the development of their agricultural sector, as it is the source of income for a large group of citizens. As a continent, Africa still suffers from poverty and insufficient financial resources. Organic agriculture in Africa is now perceived as both a great solution to improve the economy of African countries and a development path. In the case of organic production growth forecasts, Africa presents a great potential for millions of smallholder farmers and their families to exit the problem of poverty and hunger (FiBL \& IFOAM 2020, p. 192). Traditionally, African agriculture is based on low external inputs, which facilitates the system of organic agriculture to grow the productivity and resilience, and to sustain the good quality of the environment (soil, air, water, etc.). It seems that with an adequate base of research, investments, and the development of ecologically sustainable technologies/production systems, becoming more organic presages a perfect option for the development of African countries, their economies, and their citizens.

More importantly, organic agriculture, as a system that integrates traditional methods of farming and takes advantage of local, accessible, and affordable resources, is highly important for the majority of farmers in Africa. There is a strong need to support the development of organic agriculture in Africa as it encourages farmers to fight for a better future for their families. Therefore, governments and their institutions, farmers' organizations, the private sector, and development partners should invest in research programs and establish special platforms to share good practices and experience among farmers and institutions. This is the only path to build a strong basis for a vibrant economy, food and nutrition security, and to reduce poverty (FiBL \& IFOAM 2020, p. 192).

In conclusion, due to the enormous differences resulting from the weather, climate and soil conditions, the institutional and governmental environment, the financial support, and the development of technologies and modern cultivation methods, it might be extremely difficult to make a comparison between Poland and the LDCs in Africa. However, finding common challenges for the future development of the Polish organic sector and the LDCs in Africa might be important for creating future provisions on improving and supporting their organic sectors. The greatest challenges include:

- increasing trust in organic food producers,

- reduction of production costs,

- developing a network and distribution channels, 
- clearer regulations on the organization of organic production,

- increasing marketing activities to popularize ecological products,

- defining a clear and transparent strategy for the development of agricultural policy in this area,

- creating institutional support for organic farmers,

- sharing information on good practices and ecological methods of cultivation,

- increasing public awareness of the benefits resulting from the consumption of organic products and the welfare of the planet.

\section{References}

Agricultural and Food Quality Inspection (2019), The report on organic farming in Poland in 2017-2018, Warszawa.

Agricultural production - crops (2019). https://ec.europa.eu/eurostat/statistics-expla ined/pdfscache/26212.pdf (accessed: 14.05.2020).

Ancharaz, V. (2012), Can the Doha Round Be Saved?, [in:] R. Meléndez-Ortiz, Ch. Bellmann, M. Rodriguez Mendoza (eds), The Future and the WTO: Confronting the Challenges. A Collection of Short Essays, International Centre for Trade and Sustainable Development, Geneva.

Borowska, A. (2006), Rozwój rolnictwa ekologicznego na świecie na początku XXI wie$k u$, "Zeszyty Naukowe Akademii Rolniczej we Wrocławiu", no 540, pp. 79-92.

Buckley, R. (2003), The WTO and The Doha Round: The changing face of World Trade, Global Trade abd Finance Series, Kluwer Law International, Zuidpoolsingel, Netherlands, $1^{\text {st }}$ Edition.

Dugiel, W. (2008), Światowa Organizacja Handlu a kraje rozwijające się, "International Journal of Management and Economics", 24, pp. 9-37. http://bazhum.muzhp.pl /media/files/International_Journal_of_Management_and_Economics/Internatio nal_Journal_of_Management_and_Economics-r2008-t24/International_Journal _of_Management_and_Economics-r2008-t24-s9-37/International_Journal_of_Ma nagement_and_Economics-r2008-t24-s9-37.pdf (accessed: 25.05.2020).

Ecological Organic Agriculture (EOA) - Initiative, Continental Steering Committee (2015), The Ecological Organic Agriculture (EAOA) Initiative, 2015-2025 Strategic Plan, EOA Continental Steering Committee, African Union Commission, Benin.

ESCAP (2014), The role of agriculture in closing development gaps of LDCs, Policy Papers on Countries with Special Needs, CSN/14/01, United Nations Economic and Social Commission for Asia and the Pacific, Bangkok. https://www.unescap.org/si tes/default/files/CSN-14-01\%20(June)_0.pdf (accessed: 12.05.2020).

FAO (1998), Evaluating the Potential Contribution of Organic Agriculture to Sustainability Goals, Environment and Natural Resources Service Research, Extension and Training Division Sustainable Development Department Food and Agriculture Organization of the United Nations. http://www.fao.org/3/a-acl16e.pdf (accessed: 14.05.2020). 
FAO, Morgera, E., Bullón, C., Durán, C.G.M. (2012), Organic agriculture and the law, "FAO Legislative Study 107”, Rome. http://www.fao.org/3/a-i2718e.pdf (accessed: 10.05.2020).

FiBL (2019), World of Organic Agriculture Statistics and emerging trends 2019 (2019), IFOAM, FiBL, Frick-Bonn.

FiBL (2020), FiBL survey 2020, The World of Organic Agriculture Statistics and emerging trends 2020, IFOAM, FiBL, Frick-Bonn.

Gama, J. (2018), Latest Developments in Organic Agriculture in Africa, [in:] FiBL \& IFOAM - Organics International (2018): The World of Organic Agriculture: Statistics and Emerging Trends 2018, Research Institute of Organic Agriculture FiBL, Frick, and IFOAM - Organics International, Bonn. https://www.organic-world.net /yearbook.html (accessed: 10.06.2020).

Golijan, J., Dimitrijevic, B. (2018), Global organic food market, "Acta Agriculturae Serbica”, XXIII (46), Belgrade-Zemum. https://www.afc.kg.ac.rs/files/data/acta/46 /1__AAS_252-18_Golijan_and_Dimitrijevic.pdf (accessed: 3.04.2020).

https://www.wto.org/english/res_e/booksp_e/anrep19_e.pdf (accessed: 20.05.2020).

Jak państwo wspiera ekorolników (2019). https://www.nik.gov.pl/aktualnosci/rolnictw o-ekologiczne.html (accessed: 30.06.2020).

Kowalska, A. (2015), Rolnictwo ekologiczne jako czynnik rozwoju zrównoważonej konsumpcji, "Journal of Agribusiness and Rural Development", 3 (37), pp. 467-476.

Kristiansen, P., Taji, A., Reganold, J. (eds.) (2006), Organic Agriculture. A global perspective, CSIRO Publishing, Australia. https://orgprints.org/14043/1/14043.pdf (accessed: 11.05.2020).

Kuś, J., Jończyk, K. (2009), Development of Organic Farming in Poland, "Journal of Research and Applications in Agricultural Engineering”, 54 (3), pp. 178-182.

Luttikholt, L.W.M. (2007), Principles of organic agriculture as formulated by the International Federation of Organic Agriculture Movements, "NJAS - Wageningen Journal of Life Sciences", 54 (4). https://doi.org/10.1016/S1573-5214 (07)80008-X

Makowska, M., Gotkiewicz, W., Pawlewicz, A. (2015), Rolnictwo ekologiczne w ujęciu przestrzennym i środowiskowym, "Roczniki Naukowe SERiA", 4 (XVII), pp. 160-165.

Martin, W., Mattoo, A. (eds). (2011), Unfinished Business? The WTO's Doha Agenda, The World Bank, Washington.

Ministry of Agriculture and Rural Development (2020), Rolnictwo ekologiczne. https:// www.gov.pl/web/rolnictwo/rolnictwo-ekologicznel (accessed: 30.06.2020).

Runowski, H. (2003), Rolnictwo ekologiczne w Polsce na tle tendencji światowych, “Zeszyty Naukowe SGGW. Ekonomika i Organizacja Gospodarki Żywnościowej”, 49, pp. 182-193.

Schoonbeek, S., Azadi, H., Mahmoudi, H., Derudder, B., De Maeyer, P., Witlox, F. (2013), Organic Agriculture and Undernourishment in Developing Countries: Main Potentials and Challenges, "Critical Reviews in Food Science and Nutrition", 53 (9), pp. 917-28. https://doi.org/10.1080/10408398.2011.573886

Scialabba, N. (2000), Factors Influencing Organic Agriculture Policies with a Focus on Developing Countries, IFOAM 2000 Scientific Conference, Basel. http://www .fao.org/3/a-at734e.pdf (accessed: 19.05.2020). 
Scialabba, N., Hattam, C. (2002), Organic agriculture, environment and food security. "Environment and Natural Resources Series", Food and Agriculture Organization of the United Nations (FAO), Rome.

Światowy rynek produktów ekologicznych osiagną wartość 90 mld euro (2019). http:// www.portalspozywczy.pl/owoce-warzywa/wiadomosci/swiatowy-rynek-produkto w-ekologicznych-osiagnal-wartosc-90-mld-euro,169160.html (accessed: 3.12.2019).

UNCTAD (2018), Statistical Tables on The Least Developed Countries 2018, United Nations Conference on Trade and Development, Geneva.

UNCTAD (2019), State of Commodity Dependence 2019, United Nations Conference on Trade and Development, DITC/COM/2019/1/Corr.1, Geneva, https://unctad.org /en/PublicationsLibrary/ditccom2019d1_en.pdf (accessed: 29.05.2020).

Willer, H., Lernoud, J. (2019), The World of Organic Agriculture. Statistics and Emerging Trends 2019, 20 edition, Research Institute of Organic Agriculture FiBL and IFOAM Organics International, Frick-Bonn.

Wojtas, M. (2016), Negocjacje rundy Doha - postępy w czasie Konferencji Ministerialnych w Bali i Nairobi, "Finanse, Rynki Finansowe, Ubezpieczenia", 3 (81), pp. $275-284$.

World Trade Organisation (2019), Annual Report 2019, Switzerland.

WTO, Agriculture negotiations. https://www.wto.org/english/tratop_e/agric_e/negoti _e.htm (accessed: 20.05.2020).

WTO, Doha Round: what are they negotiating? https://www.wto.org/english/tratop _e/dda_e/update_e.htm (accessed: 20.05.2020).

WTO (2020a), Bali Package and November 2014 decisions, World Trade Organisation. https://www.wto.org/english/thewto_e/minist_e/mc9_e/balipackage_e.htm (accessed: 2.06.2020).

WTO (2020b), The Doha Round Texts and related documents, World Trade Organisation, Switzerland. https://www.wto.org/english/res_e/booksp_e/doha_round_tex ts_e.pdf (accessed: 20.05.2020).

Zajączkowski, M. (2018), Runda z Dohy WTO - próba przyjęcia reguł sprzyjającym interesom krajów rozwijajacych się, "Studia Ekonomiczne. Zeszyty Naukowe Uniwersytetu Ekonomicznego w Katowicach”, 372, pp. 205-219. http://cejsh.icm.edu .pl/cejsh/element/bwmeta1.element.cejsh-9db0f9cf-0a7d-4298-a16c-9da31ela5188 (accessed: 26.06.2020). 


\section{Streszczenie}

\section{Rolnictwo ekologiczne w najmniej rozwiniętych państwach na przykładzie Afryki}

W ciągu ostatnich kilku lat obserwuje się dynamiczny rozwój rolnictwa ekologicznego. Globalny obszar rolnictwa ekologicznego stale rośnie. Co więcej, rynek organiczny rozwija się nie tylko w Europie, ale także w Ameryce Północnej, a także w innych częściach świata. Rynek produktów ekologicznych stale rośnie i należy podkreślić, że w 2015 r. światowy rynek produktów ekologicznych wzrósł do 81,6 mld euro, przekraczając wartość 90 mld euro w 2018 r. Znacząco wzrosła również produkcja produktów ekologicznych , wytwarzanych przez grupę krajów najsłabiej rozwiniętych (takich jak wybrane kraje afrykańskie), które są wspierane przez postanowienia wynikające z negocjacji Światowej Organizacji Handlu w ramach Rundy z Doha. Celem tego artykułu jest przedstawienie różnych definicji rolnictwa ekologicznego według najważniejszych organizacji międzynarodowych. Ponadto kluczowe będzie zbadanie obecnego statusu sektora rolnictwa ekologicznego w wybranych przykładach krajów najsłabiej rozwiniętych w Afryce oraz określenie wyników negocjacji z Doha na rynku rolnym (szczególnie w odniesieniu do krajów najsłabiej rozwiniętych). Wreszcie należy przyjrzeć się problemowi, jaki jest stan i jakie są najnowsze osiągnięcia rolnictwa ekologicznego w odniesieniu do krajów najsłabiej rozwiniętych w porównaniu z Polską. Metody badawcze zastosowane w artykule obejmują analizę dostępnych źródeł dokumentalnych i literackich dotyczących omawianych zagadnień, opracowanie odpowiednich badań statystycznych oraz zastosowanie podejścia dedukcyjnego w celu wyciągnięcia wniosków ze statusu rozwoju rolnictwa ekologicznego w krajach najmniej rozwiniętych i Polski (jako przykładu kraju Europy Środkowej).

Słowa kluczowe: rolnictwo ekologiczne, produkty ekologiczne, zrównoważony rozwój, kraje najsłabiej rozwinięte, Światowa Organizacja Handlu, runda z Doha 